
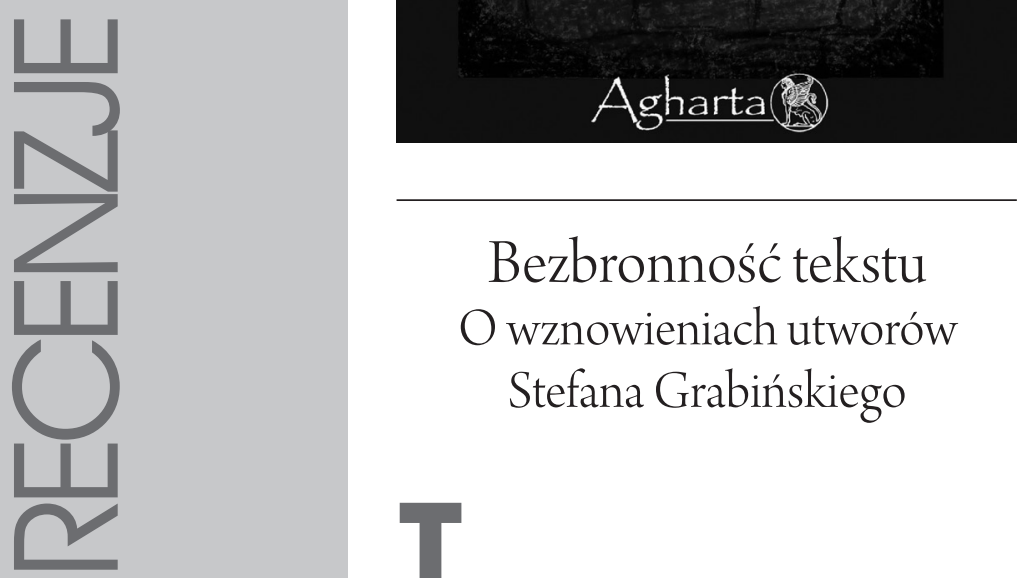

rzy minione lata przyniosły aż siedem pozycji wydawniczych z utworami Stefana Grabińskiego, niekiedy zupełnie nieznanymi, gdyż drukowanymi po raz pierwszy (i ostatni) w którymś z trudno dziś dostępnych przedwojennych czasopism. Zapewne głównym powodem tej popularności jest wygaśnięcie materialnych praw autorskich. Pozycje ze wznowionymi tekstami autora Księgi ognia można podzielić na dwie grupy. Pierwszą stanowią „Demon ruchu” $i$ inne opowiadania wydawniczego potentata, jakim jest Zysk i Spółka (Poznań 2011), oraz dwie książki Wydawnictwa Armoryka: zbiór nowel grozy Grabińskiego, Władysława Reymonta oraz współczesnego (ur. 1953) pisarza i thumacza Andrzeja Sarwy pt. Zagadka jesiennej nocy. Opowieści $z$ dreszczykiem (Sandomierz 2010) i wznowienie drugiego tomu Grabińskiego $\mathrm{Na}$ wzgórzu róż (Sandomierz 2012). Do drugiej grupy natomiast zaliczyć należy cztery książki dwóch początkujących oficyn. Są to: Wydawnictwa Agharta zbiór próz Grabińskiego i Jana Huskowskiego pt. Tragedia na wieży. Opowieści nadzwyczajne (Kraków 2011) i drugie (pierwsze powojenne) wydanie powieści Klasztor i morze (Kraków 2011); oraz dwie antologie wydawnictwa Kabort - Maski śmierci. Opowieści niezwykte (t. 2) oraz Demony perwersji. Opowieści niezwykłe (obydwie - Przemyśl 2010).

Staranne edytorsko wydanie Zysku skierowane jest do tzw. zwykłego czytelnika, który nie musi się orientować, kim był autor Wyspy Itongo. Sztywna, stylizowana na plakaty dwudziestolecia międzywojennego okładka łączy odrobinę staroświecką nowoczesność $\mathrm{z}$ aurą tajemnicy. Dobry papier, dość duża czcionka, a także możliwość łatwego otwarcia książki na dowolnej stronie, to wszystko czyni z "Demona ruchu” $i$ innych opowiadań ladny przedmiot, który bez wątpienia stanie się ozdobą niejednego bibliotecznego regału. Rekomendacja Chiny Miéville’a na czwartej stronie okładki, czyli - zgodnie z informacją zamieszczoną w tym samym miejscu - autora Dworca Perdido oraz Miasto i miasto, już tylko stanowi dopełnienie całości.

W tego typu wydaniu nie dziwi brak jakiejkolwiek noty edytorskiej, z której można by się dowiedzieć, czy redaktorzy książki korzystali z pierwodruków, czy z któregoś z wcześniejszych powojennych wydań. $\mathrm{Z}$ pewnych względów jednak informacja taka powinna się znaleźć gdzieś na końcu książki. Otóż z mniej więcej 150 znajdujących się w niej przypisów ponad połowa jest identyczna z przypisami z pierwszego, zawierającego właśnie nowele tomu Utworów wybranych Stefana Grabińskiego w opracowaniu i ze wstępem Artura Hutnikiewicza (Kraków 1980). Można by sądzić, że przepisano je „kropka w kropkę", gdyby nie to, że w edycji Hutnikiewicza kropki pojawiały się tylko wtedy, gdy wyjaśnienie przyjmowało postać zdania, w wydaniu Zysku są natomiast na końcu każdego przypisu. $\mathrm{W}$ pozostałej niecałej połowie różnice też są niewielkie, na przykład: nie informowano, z jakich języków pochodzą objaśniane słowa; niekiedy za niepotrzebny uznano cudzysłów, 
którym Grabiński opatrzył obcojęzyczne nazwy pociągów (nie zawsze zrobiono to natomiast w tekście głównym); dokonano standardowych uwspółcześnień ${ }^{1}$, raz zniknęło w obcojęzycznej wypowiedzi ostatnie słowo, parę razy definiowane hasło napisano bez żadnych szczególnych powodów wielką literą, do tego kilka przecinków, ze dwie kropki itd., itp.

Inaczej, i słusznie, bo zgodnie z kontekstem noweli Gebrowie, wyjaśniono w wydaniu Zysku słowo „kornalina”. Niekiedy jednak z różnicą idzie w parze błąd. W przypisie do słowa „Nebukadnezar” brak partykuły „nie” czyni początkową część przypisu niepoprawną składniowo, gdyż negacja występuje tu w konstrukcji typu: nie..., lecz... (poza tym przypis Zysku zgodny jest, podkreślmy, że co do kropki, z przypisem Hutnikiewicza). W innym miejscu mamy z kolei „Iucida”, zamiast poprawnego „lucida”. Poza jednym wyjątkiem w książce Zysku, podobnie jak w wydaniu Hutnikiewicza, nie zrobiono przypisów do wielu słów, które w wydaniu popularnym wyjaśnień się domagają, na przykład „roztruchan”, „śrzeżoga”, „ożóg” (włożony w wymiotło), „wnętliwy” (duszność wnętliwa). Hutnikiewicz uznał natomiast za stosowne, podobnie jak potem Zysk, objaśniać, raczej niepotrzebnie: sui generis, cogito ergo sum, spiritus movens, en bloc, The International Sportsman ${ }^{2}$.

Tak duży stopień podobieństwa pomiędzy przypisami w obydwu wydaniach musi dziwić, ale jako że Stefan Grabiński nie wierzył w przypadek, czytelnikom jego utworów nie pozostaje chyba nic innego, jak wziąć pod uwagę, że opisana powyżej koincydencja z pozoru tylko jest kontyngentna, w rzeczywistości zaś wyjaśnienie swoje znajduje w niepojętych dla zwykłych zja-

1 Porównując przypisy, zauważyłem też jedną modyfikację w tekście głównym, mianowicie "ureusy" Grabińskiego (Gebrowie, w wydaniu Hutnikiewicza s. 352) sa już w "Demonie ruchu”... ureuszam (s. 470).

2 "Demon ruchu" $i$ inne opowiadania zawiera 25 opowiadań Stefan Grabińskiego. Z wyjątkiem dwóch, Szalonej zagrody i Zemsty żywiołków, wszystkie znalazły się już w Nowelach opracowanych przez Artura Hutnikiewicza. W wydaniu Zysku 25 nowel zajmuje 540 stron. W wydaniu Hutnikiewicza 34 utwory mieszczą się na 610 stronach (ale o mniejszym formacie) wraz ze szkicem o Grabińskim i notą edytorską (razem około 20 stron). daczy chleba sferach „tajemnych znaczeń” (Cień Bafometa).

W niedużym objętościowo wyborze pt. Tragedia na wieży. Opowieści nadzwyczajne oprócz próz Jana Huskowskiego znajduje się osiem nowel Grabińskiego, które nie znalazły się w żadnym z wcześniejszych wyborów Wydawnictwa Literackiego - Opowieściach niesamowitych z posłowiem Stanisława Lema (1975) oraz wspomnianym już tomie Nowele $\mathrm{w}$ opracowaniu Hutnikiewicza. Wybór ten nie jest reprezentatywny dla Grabińskiego i zawiera również jego słabsze utwory. Wampir, Kruk czy Strych są bowiem znacznie gorsze od, na przykład, Zmory, która bez wątpienia wytrzymuje próbę czasu i choć może nie dorównuje takim perełkom, jak Czad czy Dziedzina, to jej oszczędna narracja buduje wyrazisty, przejmujący obraz. Jest to zresztą nowela bardzo osobista, pomimo swej literackości prawie wprost wyrażająca spowodowane gruźlicą poczucie osamotnienia i oddzielenia od wspaniałości życia. Ta wspaniałość zresztą przyobleka się, co zresztą wcale u tego pisarza nie zaskakuje, w nieco schematyczną symbolikę erotyczną - reprezentuje ją bowiem „dorodna, ciemnowłosa pani”, o „zdrowej, jędrnej postaci”, „pysznych biodrach”, „gibkiej kibici”; tym razem jednak erotyczny fantazmat Grabińskiego przedstawiony został w sposób bardziej ściszony, stonowany poetyką sennego obrazu, bez właściwego temu pisarzowi rozsmakowania w estetyce, by użyć jego określenia - lubieży. Nie sposób tu omawiać szczegółowo całego zbioru, zwróćmy więc uwagę przynajmniej na znakomite, estetyzujące $\mathrm{Na}$ wzgórzu ró $\dot{z}$, oparte na pojętej w duchu symbolizmu synestezji, czy Cień, zawierający miniwykład na temat symbolizmu - życiowego i artystycznego - i symboliki cienia.

Można by zapytać, dlaczego nie zamieszczono w Tragedii na wieży innych, niewznawianych wcześniej nowel ze zbiorów Grabińskiego, podobnie jak zastanawiać się nad zasadnością przypominania tekstów Jana Huskowskiego, który wprawdzie, jak Grabiński, był lwowianinem, jednak wbrew zamieszczonej na IV stronie okładki opinii redaktora zbioru, Stanisława Żuławskiego, do mistrzów, i to nie tylko polskiej noweli grozy, bez wątpienia nie należy. Można 
by też, na przykład, zauważyć, że w Zielonych Świątkach pominięto podtytuł Parafraza, są to jednak kwestie trzeciorzędne wobec skandalicznej redakcji tej książki - w tym braku zwykłej korekty, czego skutkiem są liczne błędy ortograficzne, interpunkcyjne, literowe.

Edytorska rzetelność właściwa jest natomiast opracowanej przez Jakuba Knapa i poprzedzonej jego wstępem powieści Klasztor i morze (I wyd. 1928). Knap stara się bronić niezbyt przychylnie przyjętego przez przedwojenną krytykę Klasztoru..., w legendowo-baśniowej cudowności widząc możliwość sfunkcjonalizowania „pęknięcia kompozycyjnego” pomiędzy wątkami realistycznym i fantastycznym. Jednakże obydwa wątki, dodajmy, że niestety miłosne, poprowadzone zostały przez autora Demona ruchu równolegle i są od siebie niezależne aż do momentu, gdy Heda Dorszówna wstąpi do klasztoru. Nie tyle zatem należy mówić tu o jakimś pęknięciu, co o pretekstualnym w znacznej mierze potraktowaniu fabuly, służącej ukazaniu, jak to u Grabińskiego, „spraw tajemnych” (Klasztor i morze). Bez wątpienia ma jednak rację Knap, akcentując jasny wymiar niesamowitości w tym utworze, co jest u tego pisarza bardzo rzadkie i sprawia, że z tego punktu widzenia wart jest on pewnej uwagi.

$\mathrm{Z}$ przedwojennych recenzentów Klasztoru i morza Knap przyznaje rację przychylnemu powieści Jerzemu Eugeniuszowi Płomieńskiemu, który w motywie metempsychozy widział czynnik spajający powieść. Metempsychoza jest jednak jednym z najmniej przekonujących motywów utworu Grabińskiego, zarazem - przynajmniej w postaci w jakiej się w nim pojawia - jednym z dowodów, że rozumienie niesamowitości nie zawsze przybierało u tego pisarza nowoczesną, krytyczną postać. Przede wszystkim jednak Klasztor i morze cechuje męcząca wybujałość stylistyczna, zwłaszcza w zakresie słownictwa. Język Grabińskiego, silnie osadzony w polszczyźnie przełomu wieków XIX i XX, o ciekawej, plastycznej składni, wzbogacany regionalizmami, archaizmami i makaronizmami, ale i - zapewne - również neologizmami, dziwacznymi niekiedy, kiedy indziej zaś może nawet nieudanymi, w Klasztorze... znalazł się w stanie jakiejś niespokojnej (histerycznej?) intensywności. Nagromadzenia leksyki kaszubskiej, klasztornej czy żeglarskiej - dość często zdarzają się dłu- gie wyliczenia ptaków, leczniczych roślin, rybackich sprzętów - nie tyle odrealniają świat przedstawiony, co czynią go przede wszystkim sztucznym; zastyga on w słowie, tak jak zastyga w schematyzmie emocjonalnym lub metafizycznym. Dodajmy może, że językowa dziwność tej powieści jest dość ciekawym przykładem młodopolskiej maniery, jej sztuczności, którą w prozie dwudziestolecie międzywojennego uda się sfunkcjonalizować blisko dekadę później dopiero Brunonowi Schulzowi. Grabiński jednak, łącząc ze sobą różne „języki”, osiąga często efekt, jak się wydaje, niezamierzonego komizmu - na przykład rozmowa dwóch sióstr zakonnych na temat piętnastowiecznego dzwonu przypomina sprawozdanie z panelowego spotkania na konferencji historyków sztuki.

Osobny problem stanowią przypisy do Klasztoru i morza, jest ich ponad 300, znaczna część pochodzi od redakcji i jak można przeczytać w Uwagach edytorskich, „starano się dodatkowo nie «obciążać» książki objaśnieniami i zrezygnowano z nich tam zwłaszcza, gdzie wyrazy zrozumiałe były w kontekście”, co jest o tyle zaskakujące, że wyjaśniano takie słowa i zwroty, jak „opoka”, „spłacheć”, „rzeszoto”, ad rem, „korab”. Czy współczesny czytelnik na pewno wie, co znaczy „klauzura” lub „ermitaż”, czy odróżnia „stelę” od „stalli”? Kolejna sprawa to ingerencja $\mathrm{w}$ przypisy autorskie. We wspomnianych Uwagach edytorskich czytamy, że w niektórych przypadkach zmieniono pozycję ich występowania, aby odnosiły się do pierwszego użycia wyjaśnianego słowa, co „wymusiło niekiedy zmianę formy gramatycznej autorskiego objaśnienia”. Redaktorowi tej książki nie udało się jednak uniknąć tego typu usterek: „kompletę” wyjaśniono na s. 17, choć pojawiła się już na 15; przypis do „eremu” pojawia się na stronie 32 , choć słowo występuje już na 26; zanim na stronie 52 pojawi się wyjaśnienie Grabińskiego, że „belnota” to 'dzielność, wielokrotnie użyty zostanie w powieści przymiotnik „belny”.

Z punktu widzenia osób zainteresowanych twórczością Grabińskiego drugi tom antologii Maska śmierci przedstawia dużo większą wartość niż Demony perwersji. Prezentuje on poza opowiadaniami Gustava Meyrinka, Karla 
Hansa Strobla, Oskara Panizzy i Wiktora Eryka Fossegrima (zarazem tłumacza trzech nieodnotowanych $\mathrm{w}$ spisie treści wierszy Poego $)^{3}$ 14 utworów Grabińskiego - w większości przedruków z czasopism, i dodatkowo w aneksie cztery krótkie, kilkuwersowe prozy oraz fragmenty noweli Ironia, w spisie treści niezbyt precyzyjnie nazwane razem „utworami poetyckimi”. Jeśli chodzi o Demony perwersji, to te z kolei zawierają - obok utworów Poego, Meyrinka i Hansa Heinza Ewersa - siedem nowel Grabińskiego (i tu najlepsze są Zmora i Na wzgórzu róż).

Spośród wszystkich omawianych w tej recenzji pozycji właśnie Maska śmierci, zawierając w większości utwory $\mathrm{z}$ lat 30., i to publikowane przede wszystkim w czasopismach, w największym stopniu przyczynia się do zmiany w dotychczasowym wizerunku Grabińskiego, na przykład portową opowieścią Sympatyk Proń, nowelami „orientalnymi” albo Porumbica czy Wizytą. Wątków fantastycznych jest w tych tekstach jakby mniej, niektóre oscylują wręcz ku realizmowi. Ostatnia z wymienionych, Wizyta, której akcja osadzona została, wedle jej słów, w „ukochanym Lwowie”, jest bardziej studium psychologicznym zniszczonej nieudanym życiem i chorobą kobiety, w którym osnuta „woalem” łagodnej melancholii niesamowitość - ma w niej też udział miasto - zostaje dość mocno, powiedzmy, uzwyczajniona.

Antologiom Kaborta, mimo, jak można sądzić, autentycznej pasji redaktorów - Krzysztofa Bortnika i Krzysztofa Macieja Choulego - oraz ich niemałej wiedzy w zakresie literatury grozy i pisarstwa Grabińskiego, właściwa jest pewna redakcyjno-edytorska niepowaga. Widać to już we wstępach do nich, w ich informacyjnym nadmiarze, przesadnie rozbudowanych przypisach z wyliczeniami adresów bibliograficznych, tytułów nowel Grabińskiego lub tłumaczonych

3 Językowe cechy nowel Fossegrima, fakt, że nazywa się on tak, jak jeden ze skandynawskich duchów wodnych, a redaktorzy antologii sami zdaja się nic nie wiedzieć o jego biografii, pozwalają zaryzykować stwierdzenie, że mamy tu do czynienia z dość zręczną, ujawniającą jednak szwy mistyfikacją, a rozbudowana, "stylizowana” składnia wstępów do obydwu antologii i upodobanie w obco i archaicznie brzmiącej leksyce („tudzież”, „eksplorować”) zdaje się zdradzać jednego z ich autorów. na język polski utworów Poego, Meyrinka czy Strobla, w długich i nużących akapitach, szeregujących nowele $\mathrm{z}$ antologii wedle zasady tematycznej bądź formalnej jednorodności. $\mathrm{Z}$ tych względów obydwa wybory łączą w sobie cechy antologii opowiadań grozy z elementami książki pokonferencyjnej (w tym wypadku: nie najlepszej próby akademizm) ${ }^{4}$. Odnieść można bowiem wrażenie, że zatytułowane $O d$ redakcji wstępy to fragmenty prac magisterskich, uzupełnione o ściśle redakcyjne informacje i zamieszczone na początku obydwu zbiorów bez świadomości, że konwencja tego typu wprowadzeń jest całkowicie odmienna (jakby ich redaktorom nieznana była forma noty edytorskiej, znakomicie wszak nadająca się do prezentowania spraw mniej lub w ogóle nieinteresujących zwykłego czytelnika, do którego jednak w znacznej mierze te antologie są skierowane).

Poważne powody do niepokoju daje ponadto ujawnienie w obydwu wstępach części zasad, wedle których opracowano utwory Grabińskiego. Redaktorzy Maski śmierci informują na przykład, że pominęli, „jako mało istotne wszelkie okolicznościowe dedykacje” i nie uwzględnili podtytułów (te ostatnie na szczęście podając we wstępie), gdyż uznali je „za efemeryczne [sic!], niekiedy wręcz za nieadekwatne”. Nie wiadomo, dlaczego inaczej niż w odniesieniu do licznych, grzeszących nadmiarem wyliczeń tułów i adresów bibliograficznych oraz nie zawsze potrzebnych informacji, dedykacji nie podano choćby $\mathrm{w}$ przypisie. $Z$ kolei uzasadnienie, że w przypadku opowiadania Porumbica. Z dziennika podró$\dot{z} y$ do Rumunii utwór ten nie ma nic wspólnego z dziennikiem, zupełnie nie przekonuje, tym bardziej że diarystyka nie jest czymś jednolitym, a gatunkowe "gry" są stałą cechą nowelistyki Grabińskiego. Nawet w Opowieści o grabarzu, której podtytuł Gawęda zaduszna usunął sam Grabiński, sprawa nie jest prosta, gdyż w pierwodruku nie zdaje się on pojawiać jedynie ze względu na okoliczności druku („zaduszkowy” numer czasopisma), ale ma swoje uzasadnienie

4 Wrażenie takie pogłębia zamieszczenie w aneksie Demonów perwersji - dodajmy, że obok eseju Poego Instynkt a rozum - trzech artykułów, autorstwa m.in. jednego $z$ redaktorów, na temat ekranizacji utworów Grabińskiego i Meyrinka.

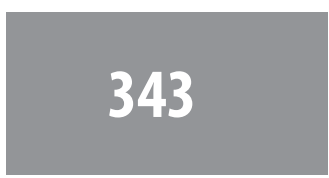


zarówno w treści noweli, jak i w tych jej fragmentach, w których mowa jest o opowieściach i gawędach, w tym również „gawędach cmentarnych”. Być może, jak czytamy we wstępie do Demonów perwersji, Grabiński traktował niekiedy podtytuły swoich nowel instrumentalnie, nadając je ze względów pozaartystycznych, na nic takiego jednak nie wskazano przy Kruku czy Królu Nenufarze.

Nieufność budzi również uznanie, bez podania jakichkolwiek kryteriów, niektórych zwrotów Grabińskiego za „«dziwotwory» językowe”. Taka opinia stałaby się wiarygodna dopiero po bardziej szczegółowych argumentach natury językoznawczej, uwzględniających specyfikę języka Grabińskiego, który w swoich utworach próbował wszak wyrazić dziwność świata (jego niesamowitość i niepojętność), co siłą rzeczy domaga się „mowy dziwnej". W każdym razie piszącemu te słowa nie wydaje się wcale, by „dziwotworami” były, na przykład: „tak był rzęsny sprzęt” ('obfity zbiór'); „bezdźwięcznym pohutnywaniem tyjad” czy „dościga rzęsny płód drzew” (dawne znaczenie „dościga”: 'dojrzewa'). Dziwi też poprawianie niektórych form, takich na przykład, jak „kurytarz”, „słych”, „udarujęć”, „wnętrznego”.

W obydwu wyborach Kaborta niejasne jest (jeśli jest) kryterium, na podstawie którego wyjaśniano niektóre mało znane słowa, inne zaś pozostawiono bez komentarza. Rozczulającą amatorszczyznę widać w objaśnieniach do „wądół” czy „przetak”, którego wyjaśnienie redaktorzy uznali za konieczne aż trzykrotnie. Zdarzają się też, niestety, błędy ortograficzne (Maski..., s. 218, 234). Do urozmaiceń lektury antologii Kaborta należy konieczność ciągłego czuwania, by książka nie zatrzasnęła się czytającemu przed nosem (rozwarcie jej również wymaga pewnego samozaparcia).

W Zagadce jesiennej nocy Wydawnictwa Armoryka zamieszczono szlagiery Grabińskiego: Dziedzinę, W domu Sary i Kochankę Szamoty (tym razem również bez przypisów). Na stronie redakcyjnej obydwu książek tej oficyny nie wspomniano ani słowem o korektorze, zauważmy więc jedynie, że w obydwu zdarzają się błędy literowe, interpunkcyjne i stylistyczne, a nawet ortograficzne, co ciekawe jednak, w Zagadce... przede wszystkim w opowiadaniach Andrzeja
Sarwy. Z kolei w zbiorze Na wzgórzu róż występują błędy redakcyjne powstałe prawdopodobnie przy skanowaniu (ściągnięcia tekstu, przeinaczenia słów typu „stoi” zamiast „stół”, „sentyzyw” zamiast „sensytyw”).

Liczne wznowienia utworów Stefan Grabińskiego nie dają zbyt wielu powodów do radości, przynajmniej tym czytelnikom, w wypadku których o uznaniu dla pisarza decyduje nie tyle predylekcja do „widmowych żywiołów, magii czarnych i białych" (Stanisław Lem), wiedzy tajemnej czy różnej maści demonów, ile świadomość artystycznej i ideowej rangi tego staroświeckiego modernisty. Językowo-redakcyjny wymiar większości omówionych książek jeszcze ten smutek pogłębia. Grabiński staje się twórcą zapomnianym, od ponad 50 lat nie napisano o nim żadnej książki, choć jest to pisarz modnej dziś grozy, a i jego „spirytualizacja żądzy” (Cień Bafometa) mogłaby się doczekać osobnego, obszernego opracowania. Na przeszkodzie ku nowemu syntetycznemu ujęciu jego pisarstwa zdają się stać przynajmniej trzy okoliczności. Po pierwsze, pewna staroświeckość Grabińskiego, która dość często wcale nie jest wadą jego utworów, przeszkadza jednakże w dostrzeżeniu nowoczesnego, realnego wymiaru ich problematyki. Po drugie, erudycja pisarza - rzadko za akademickimi omówieniami jego twórczości stoi wiedza z zakresu historii kultury końca XIX i początków XX wie$\mathrm{ku}$ : okultyzmu, parapsychologii, teorii poznania, „psychopatologii” (psychologii i psychiatrii) tamtej epoki, ale i z takich dziedzin, jak folklorystyka, kultura antyczna czy historia literatury przełomu Młodej Polski i dwudziestolecia międzywojennego (tzw. trzecie pokolenie modernistów).

Po trzecie, trzeba zarazem pamiętać, że autor Kochanki Szamoty to pisarz „nierówny”, który ulegał melodramatycznym i sensacyjnym schematom, o czym pisał swego czasu Stanisław Lem, a klarowna kompozycja jego nowel wynikała niejednokrotnie $\mathrm{z}$ dążenia do wyrazistego zakończenia fabularnego. Stąd między innymi tak często „katrupił” swoich bohaterów w zakończeniach utworów. Znakomitym tego przykładem jest nowela Płomienne gody - studium dewiacji: główny bohater odczuwa podniecenie seksualne jedynie w trakcie pożaru, a jego żona, 
która z miłości do niego ulega tej, powiedzmy, fascynacji, popada $\mathrm{z}$ tego powodu $\mathrm{w}$ obłęd przemienia się $\mathrm{w}$ schematyczną opowieść o zazdrości, szybko zmierzającą ku zakończeniu, „okraszonemu” trzema trupami: zabójstwem wiarołomnej, jej kochanka i wreszcie samobójstwem. Wyraźnie widać w tym utworze, że nie starczyło Grabińskiemu inwencji na doprowadzenie do końca odnowionej w interesujący sposób analogii ognia i erotycznej namiętności (płomienność).

Wspomniana „nierówność” Grabińskiego nie zmienia jednak faktu, że warto (nie tylko w znaczeniu ekonomicznym) i należy go wydawać, jednakże dużo staranniej, w sposób, który wzbudzi zaufanie do językowo-redakcyjnych rozstrzygnięćs.

Radosław Sioma - doktor habilitowany, adiunkt w Instytucie Literatury Polskiej Uniwersytetu Mikołaja Kopernika w Toruniu, badacz literatury XX wieku (m.in. pisarstwa Zbigniewa Herberta, Leopolda Buczkowskiego i Jerzego Szaniawskiego). Autor książki Niewinność i doświadczenie. O komediopisarstwie Jerzego Szaniawskiego (2009).

${ }^{5}$ PS z OSTANIEJ CHWILI. Udało mi się znaleźć jeszcze jedną książkę z utworami Grabińskiego, która ukazała się ostatnio, mianowicie e-booka Wydawnictwa Tryton pt. Księga ognia. Szalony pątnik (Kraków 2011) Wbrew tytułowi jest to jedynie wybór z obydwu zbiorów Grabińskiego. Z notki zawartej na ostatniej stronie, która pełni zarazem funkcje okładki (przynamniej w sensie estetycznym i informacyjnym), można by wywnioskować, że Księga ognia składa się z sześciu opowiadań („to sześć niesamowitych opowieści”), co nie jest prawda, gdyż w skład tego zbioru wchodzi dziewięć utworów. Kto wie, może niepodpisany zespół redakcyjny („pracownia edytorska” - jak to określono na stronie redakcyjnej - odpowiedzialna za redakcję i korektę) zamierzał zamieścić w Księdze ognia. Szalonym patniku sześć tekstów, ale chyba się nie udało, gdyż jest ich tylko pięć. Natomiast z dziewięciu nowel Szalonego patnika omawiany przedruk zawiera siedem.

Pospieszne przejrzenie tej książki pozwala zauważyć, że albo nie zredagowano tekstu po zeskanowaniu albo zrobiono to niedokładnie: na stronie 7 na przykład wypowiedź bohatera zlewa się z narracją; z kolei w $\mathrm{Mu}$ zeum dusz czyśćcowych brakuje dwóch mott, a cytat z Boskiej komedii "zamienił się" w prozę i zawiera liczne błędy, nie mówiąc już, że nie podano jego tłumaczenia.

I to już naprawdę koniec, bez względu na to, ile jeszcze wydawnictw postanowiło wydać (na pastwę demonów druku) utwory Grabińskiego.
Michał Kaczmarek, Proza pamięci. Stanisława Vincenza pamięć i narracja, Wydawnictwo Adam Marszałek, Toruń 2009, ss. 466.

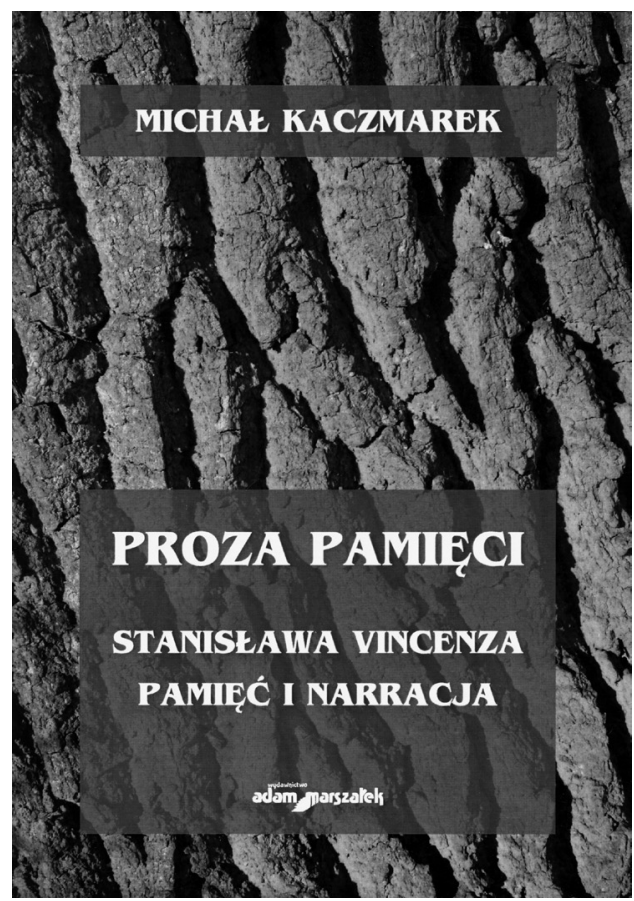

\section{Upojeni wodami Lethe i Eunoe}

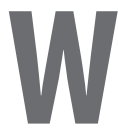

pracy Proza pamięci. Stanisława Vincenza pamięć i narracja Michał Kaczmarek nie tylko sprostał ogromnemu wyzwaniu, jakim jest dla każdego badacza twórczości Stanisława Vincenza dogłębne poznanie jego tetralogii - Na wysokiej połoninie, ale zaproponował także narzędzia do zrekonstruowania wszechobecnej w opus magnum Vincenza kategorii pamięci.

Książka składa się z dwóch części - teoretycznej oraz historycznoliterackiej. Pierwsza część - Proza pamięci - pamięć w prozie, jak podkreśla sam autor, jest przeznaczona głównie dla czytelnika zainteresowanego teorią literatury, druga zaś - Stanisława Vincenza pamięć $i$ narracja to materiał dla historyka literatury 